\title{
YOUTUBE: TROBOSAN MEDIA PEMBELAJARAN EKONOMI BAGI MAHASISWA
}

\author{
Dwi Iga Luhsasi, Universitas Kristen Satya Wacana \\ dwi.luhsasi@staff.uksw.edu \\ Arief Sadjiarto, Universitas Kristen Satya Wacana \\ arief.sadjiarto@staff.uksw.edu
}

\begin{abstract}
ABSTRAK
Penelitian ini berangkat dari permasalahan penggunaan media pembelajaran berbasis teknologi. Seiring berjalannya waktu, media pembelajaran berbasis teknologi semakin dibutuhkan. Hal ini disebabkan berubahnya gaya hidup para remaja/mahasiswa yang lebih menyukai belajar dengan menggunakan teknologi, khususnya dari YouTube. Pemanfaatan YouTube di Indonesia untuk media pembelajaran ekonomiakuntansi belum digunakan secara maksimal. Tidak banyak yang menyajikan materi-materi kuliah atau mata pelajaran ekonomi-akuntansi. Video pembelajaran terkait yang sudah adapun belum dapat merepresentasikan konten dengan menarik. Selain itu, kebanyakan media YouTube digunakan untuk pembelajaran dibidang seni dan hobi. Subjek penelitian terdiri dari subjek uji pakar dua orang, dan subjek uji coba yang adalah 24 mahasiswa Program Studi Pendidikan Ekonomi FKIP UKSW. Hasil penelitian menujukkan produk video pembelajaran berbasis YouTube yang dikembangkan layak digunakan sebagai media pembelajaran ekonomi-akuntansi dan diharapkan untuk penelitian di masa yang akan datang mampu mengembangkan lagi media pembelajaran sejenis berbasis YouTube.

Kata Kunci: Media Pembelajaran, YouTube, Pembelajaran Ekonomi-
\end{abstract} Akuntansi

\begin{abstract}
This study starts from the problem of the using of technology-based learning media. Nowadays, this media more needed. Why? Because students more like learn using the technology than using the conventional method. But the utilization of economic-accounting learning media not being used optimally. There are economic-accounting learning media on YouTube have no interesting content. Contents that show on YouTube are about the hobby and art. So, the aim of this study is to know the properness of technology-based learning media development on YouTube. The subjects of this study are 2 expert test subjects and 24 trial test subjects. Trial test subjects are students of Economic Education FKIP UKSW. The result of this study is technology-based learning media can be used by students. This media proper as economic-accounting's learning
\end{abstract}


media. Hopefully, in the future studies can be able to improve the economic-accounting learning media on YouTube.

Keywords: Learning Media, YouTube, Economic-Accounting learning

\section{PENDAHULUAN}

Seiring berjalannya waktu, teknologi juga semakin berkembang menjadi lebih canggih. Begitu pula dengan media pembelajaran. Pada umumnya, media pembelajaran yang digunakan merupakan media pembelajaran konvensional, seperti buku. Kebanyakan orang, khususnya remaja saat ini kurang menggemari media pembelajaran yang tradisional karena dianggap membosankan dan sulit untuk dimengerti (Wahono, 2010). Di sisi lain, remaja membutuhkan pengetahuan yang dapat diaplikasikan dalam pelajaran atau kehidupan sehari-hari. Media yang dimaksud merupakan peralatan fisik untuk membawakan atau menyempurnakan isi pembelajaran sebagai salah satu komponen dari suatu sistem penyampaian (Anitah, 2012: 5). Sementara itu, media pembelajaran dapat diartikan sebagai alat bantu, metode, dan teknik yang digunakan dalam kegiatan belajar mengajar supaya interaksi antara guru dan siswa bisa efektif (Nugrahani, 2007). Media pembelajaran terbagi menjadi dua yaitu metode pembelajaran konvensional dan inovatif (Ali, 2009). Salah satu contoh media pembelajaran inovatif yaitu media pembelajaran berbasis internet, khususnya Youtube.

Media pembelajaran yang modern seperti Youtube saat ini sangat digemari oleh para remaja akibat dari perkembangan teknologi tersebut. Youtube merupakan situs video sharing yang berfungsi sebagai sarana untuk berbagi video secara online (Sianipar, 2013). Media ini dianggap lebih dapat memberikan informasi yang lebih luas (Setyorini, 2016). Banyak toturial dan konten yang disajikan dalam Youtube. Seperti contohnya tutorial bermain alat musik, tutorial public speaking, kerajinan tangan, pengenalan kebudayaan daerah, dan masih banyak lagi. Video yang disajikan dalam Youtube memberikan kemudahan untuk langsung mempraktekan konten yang sedang ingin dipelajari (Wibawa, 2017). Berangkat dari kemudahan inilah yang membuat kebanyakan orang lebih menyukai belajar dengan media pembelajaran Youtube dibandingkan dengan media pembelajaran tradisional.

Luasnya informasi yang disajikan dalam Youtube, selain memberikan dampak yang positif juga memberikan dampak yang negatif. Dampak negatifnya antara lain, video mengenai toturial makeup membuat anak-anak tumbuh dewasa sebelum waktunya, atau yang lebih ekstrim lagi yaitu video pendidikan seks memicu timbulnya tindak asusila pada kalangan remaja atau anak-anak (Widiartanto, 2016). Masih banyak lagi dampak negatif yang timbul dari informasi dalam Youtube. Dampak negatif tersebut dapat diminimalisir, salah satunya dengan cara memberikan informasi yang berisi materi-materi pelajaran (Bere, 2016). Pemanfaatan Youtube sebagai media pembelajaran dapat membuat penggunanya menambah hal-hal yang positif terkait pengetahuan. Konten-konten pelajaran yang disajikan dengan menarik akan memicu penggunanya untuk memperdalam materi yang sedang dipelajari (Nistanto, 2017). Oleh karena itu, penambahan hal-hal positif dalam media pembelajaran Youtube dianggap penting. 
Dampak positif yang dihasilkan dari media pembelajaran YouTube antara lain dapat mempermudah penyebaran video storytelling pendidikan agama (Hess, 2014). Selain itu, video tutorial yang disajikan sangat bermanfaat untuk pembelajaran dan meningkatkan minat seseorang dalam belajar (Pritandhari dkk, 2015). Salah satu minat belajar terlihat dari meningkatnya viewer video-video pembelajaran, seperti belajar berbahasa asing melalui video-video sehingga kemampuan berbahasa asing meningkat (Combe et.al., 2016). Vlog yang menjadi salah satu contoh media pembelajaran di YouTube dapat dikatakan layak digunakan sebagai media pembelajaran dan dapat meningkatkan antusiasme belajar (Darmawan, 2016). Vlogging ini dapat membangun rasa percaya diri dalam mengungkapkan pendapat atau opini siswa (Snelson, 2015). Kemampuan prestasi oral juga dapat meningkat secara signifikan seiring dengan meningkatnya penggunaan video blogging (Hung et.al., 2015). Adanya dampak positif tersebut, dapat dikatakan bahwa media pembelajaran melalui YouTube dapat meningkatkan performa belajar setiap orang (Krasna et.al.,2014).

Berdasarkan penelitian-penelitian yang sudah dilakukan sebelumnya, banyak membahas penggunaan YouTube dalam mengasah ketrampilan seni dan softskill. Hanya sedikit yang membahas video pembelajaran pada subjek materi ekonomi-akuntansi. Oleh karena itu, perlu untuk membahas pengembangan media pembelajaran berbasis YouTube untuk materi ekonomiakuntansi. Pengembangan penyajian materi ekonomi-akuntansi diperlukan supaya para pengguna, khususnya siswa, menyadari pentingnya pengetahuan ekonomi (Hamzah, 2013). Konten mengenai ekonomi-akuntansi yang disajikan dengan ringan dan menarik kemungkinan akan mudah diaplikasikan dalam pengerjaan tugas dibidang akademik. Contohnya, cara untuk membuat persamaan akuntansi dapat diterapkan bila sebelumnya sudah memahami konsep persamaan akuntansi.

Sering kali materi ekonomi yang disampaikan pada pembelajaran konvensional terbatas masalah waktu sehingga perlu untuk menambah pembelajaran berbasis teknologi seperti YouTube (Riyana, 2008). Sedangkan saat ini tidak banyak disajikan video menganai materi ekonomi di YouTube. Oleh sebab itu, materi ekonomi dianggap perlu untuk ditambahkan dengan menggunakan media pembelajaran YouTube. Berdasarkan fenomena tersebut, penelitian ini bertujuan untuk: (1) memberikan arahan terkait tahap-tahap pengembangan media pembelajaran ekonomi-akuntansi berbasis YouTube, (2) mengetahui kelayakan video pembelajaran tersebut sebagai media pembelajaran. Manfaat yang diperoleh dari penelitian ini meliputi mengembangkan ketrampilan pembuatan video tutorial di kalangan mahasiswa.

\section{METODE PENELITIAN}

Penelitian ini merupakan penelitian pengembangan atau yang sering disebut dengan R\&D. Produk yang dihasilkan dari penelitian ini merupakan video pembelajaran ekonomi-akuntansi berbasis YouTube. Pengembangan media pembelajaran ini didasarkan pada Permendikbud No.24 tahun 2016 KD 3.2 untuk SMA kelas XII "Mendeskripsikan konsep persamaan dasar akuntansi". Prosedur pengembangan yang digunakan mengadaptasi model 
pengembangan Borg \& Gall dalam Sukmadinata (2007) yang terdiri dari: (1) tahap studi pendahuluan, (2) tahap penyusunan rancangan produk, (3) tahap pengembangan dan evaluasi.

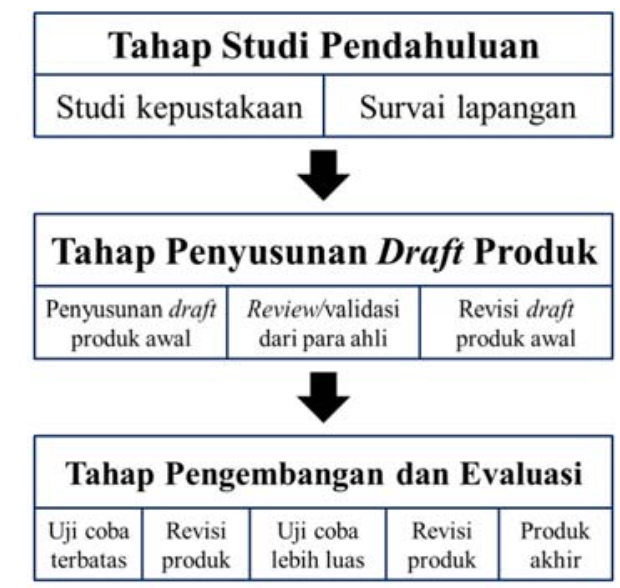

Gambar 1. Tahapan Penelitian dan Pengembangan

Angket uji pakar dan angket siswa digunakan dalam aspek penelitian yang disusun dengan memodifikasi komponen dan instrumen pengembangan bahan ajar berbasis TIK (Kemendiknas, 2010, 18-21). Angket menggunakan skala Likert dari skala 1 (sangat tidak setuju) sampai 5 (sangat setuju). Terdapat dua pakar yang dipilih untuk memvalidasi draf video pembelajaran tersebut. Dua pakar tersebut terdiri dari pakar bidang pendidikan ekonomiakuntansi dan pakar media pembelajaran. Setelah draf video pembelajaran tersebut divalidasi oleh para pakar menggunakan lembar evaluasi pakar materi dan media. Langkah berikutnya adalah merevisi draf sesuai dengan saran para pakar. Draf yang telah selesai direvisi sudah dianggap layak untuk dipublikasikan pada YouTube. Tahap selajutnya dilakukan uji coba kepada 24 mahasiwa Pendidikan Ekonomi FKIP UKSW yang sedang mengambil mata kuliah Dasar Akuntansi. Kelayakan pengembangan media pembelajaran pada penelitian ini diukur dari hasil uji pakar dan uji coba.

\section{HASIL PENELITIAN DAN PEMBAHASAN}

\section{Tahap Studi Pendahuluan}

Pada tahap ini, peneliti mengkaji teori dan konsep yang berkaitan dengan media pembelajaran berbasis YouTube. Pertama, kajian dilakukan terhadap muatan kompetensi dasar pada kurikulum 2013 untuk SMA kelas XII dari Permendigbud No. 24 tahun 2016 yaitu KD 3.2 "Mendeskripsikan konsep persamaan dasar akuntansi". Selain itu, dilakukan kajian studi pustaka yang berasal dari penelitian terdahulu. Pengembangan video pembelajaran dimanfaatkan untuk mempermudah penyebarluasan Pendidikan agama (Hess, 2014). Pernyataan ini dikuatkan dengan adanya temuan bahwa video pembelajaran saat ini lebih diminati oleh siswa dari pada media pembelajaran konvensional (Susanto, 2014). Video pembelajaran dapat disebarluaskan menggunakan laman YouTube (Mayoral et.al., 2010). Selain itu, pengembangan media pembelajaran berbasis YouTube yang telah dilakukan 
yaitu video anatomi jantung manusia (Raikos et.al., 2014), dan video dokumenter KPS (Yuniati, 2014). Vlogging dan video pembelajaran berbasis YouTube dapat membangun rasa percaya diri, meningkatkan ketrampilan berbicara (Snelson, 2015), meningkatkan kemampuan berbahasa (Combe et.al., 2016), dan meningkatkan antusiasme belajar (Darmawan dkk, 2016, dan Pritandhari, 2015). Pada penelitian-penelitian tersebut masih berfokus pada dampak pembelajaran berbasis YouTube dan Vlog. Sementara itu, penelitian pengembangan media pemeblajaran berbasis YouTube masih sedikit dilakukan. Berdasarkan hasil kajian penelitian terdahulu, penelitian ini bertujuan untuk mengembangkan media pembelajaran berbasis YouTube pada materi Ekonomi-Akuntansi.

Studi lapangan yang telah dilakukan meliputi pencarian penyajian materi ekonomi-akuntansi yang disajikan pada YouTube. Setelah dicoba dengan beberapa kata kunci, materi ekonomi-akuntansi yang disajikan masih sedikit. Guna memperkuat alasan dibutuhkannya pengembangan media pembelajaran berbasis YouTube untuk materi ekonomi-akuntansi ini, dilakukan observasi pada kelas mahasiswa konsentrasi akuntansi di PE FKIP UKSW dan diajukan beberapa pertanyaan seputar video tersebut. Berdasarkan hasil amatan awal, terlihat bahwa para mahasiswa lebih mudah mengingat dan memahami materi ketika materi disajikan melalui video. Adanya komposisi lagu; warna; dan gerak-gerik objek yang ada dalam video, dapat membatu mahasiswa untuk mengingat materi yang disampaikan. Video pembelajaran tersebut juga dapat membantu mahasiswa lebih memahami materi yang sudah dijelaskan oleh dosen. Oleh karena itu, penelitian pengembangan video pembelajaran ekonomi-akuntansi berbasis YouTube perlu dilakukan.

\section{Tahap Penyusunan Draf Produk}

Pengembangan media pembelajaran berbasis YouTube yang mengacu pada Permendikbud No. 24 tahun 2016 KD 3.2 "Mendeskripsikan konsep persamaan dasar akuntansi" memiliki kemudahan untuk diakses oleh para pengguna. Guna mengakses video pembelajaran ini, pengguna minimal harus terhubung dengan jaringan internet dan memiliki gadget (seperti laptop, tab, dan smartphone) yang compatible dengan aplikasi YouTube. Adapun tampilan video pembelajaran pada penelitian ini meliputi:

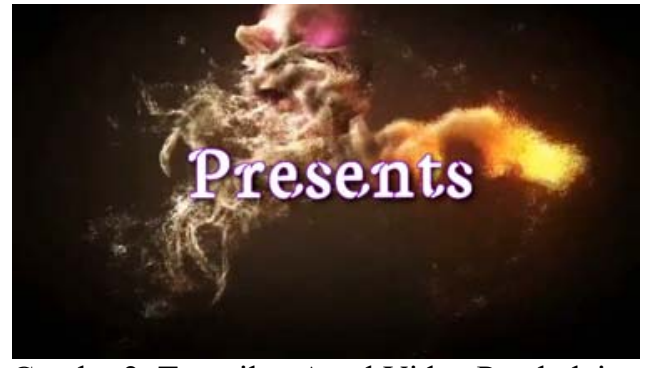

Gambar2. Tampilan Awal Video Pembelajaran

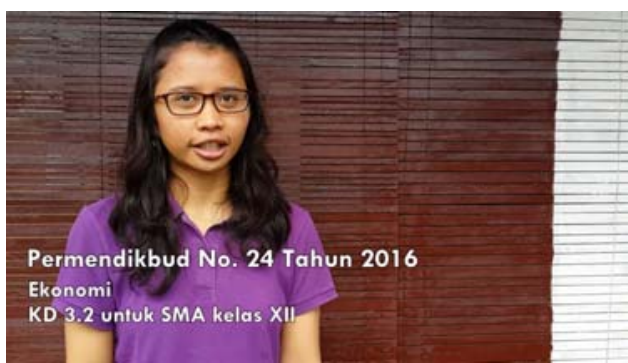

Gambar 3. Tampilan KD yang Diacu

Gambar 2 dan 3 merupakan tampilan awal yang dapat dilihat oleh para pengguna, khususnya mahasiswa. Tampilan ini memperkenalkan materi yang akan dijelaskan dan kompetensi dasar yang dipakai sehingga mahasiswa 
memiliki gambaran materi apa yang akan dibahas. selain itu, pada tampilan ini juga diarahkan masuk pada pembahasan.

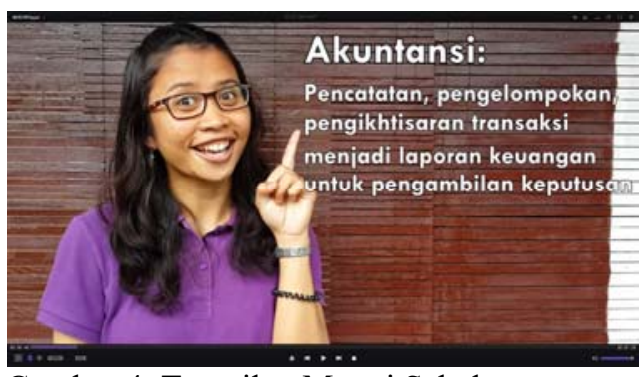

Gambar 4. Tampilan Materi Sebelumnya

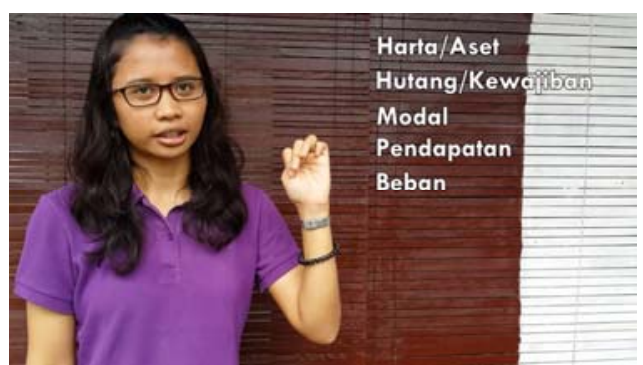

Gambar 5. Tampilan Materi Pengantar

Pada Gambar 4 menjelaskan materi yang sebelumnya dipelajari. Tampilan ini bertujuan untuk mengingatkan kembali materi yang telah dipelajari. Gambar 5 memperlihatkan materi pengantar yang menjadi dasar masuk pada materi persamaan akuntansi. Sebelum mulai membahas persamaan akuntansi, mahasiswa perlu diingatkan kembali akun-akun yang digunakan untuk menyusun persamaan akuntansi.

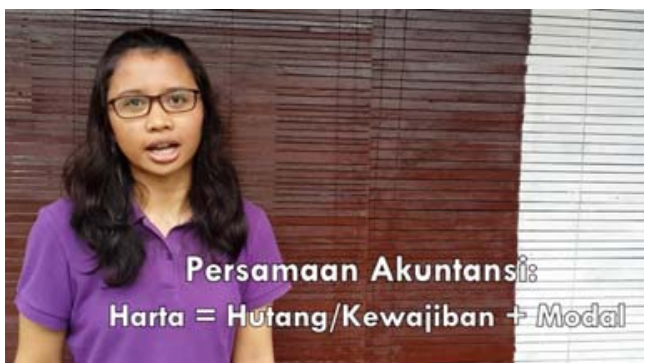

Gambar 6. Tampilan Materi Inti

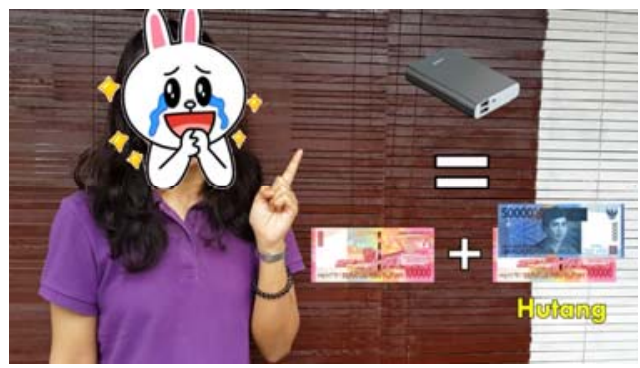

Gambar 7. Tampilan Contoh Pertama

Materi yang akan dibahas pada video pembelajaran ini terlihat pada Gambar 6. Tampilan ini menjelaskan persamaan akuntansi. Selanjutnya diberikan contoh dalam kehidupan sehari-hari bagaimana persamaan akuntansi diterapkan. Contoh penerapan persamaan akuntansi pada kehidupan sehari-hari ini terdapat di Gambar 7.

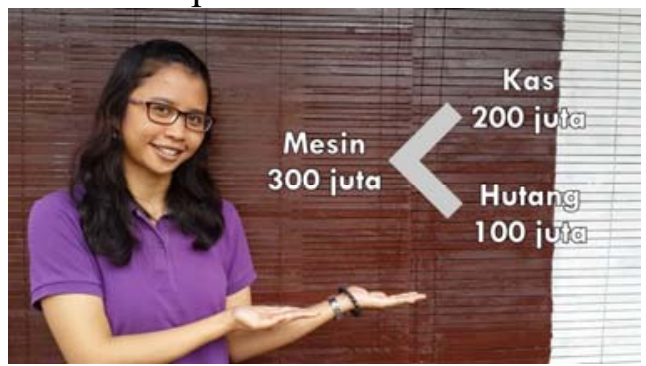

Gambar 8. Tampilan Contoh Kedua

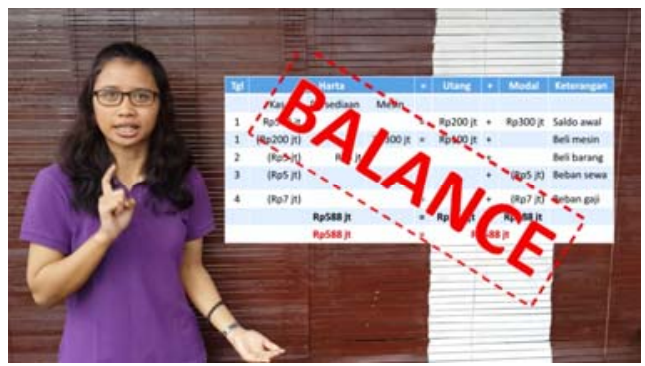

Gambar 9. Tampilan Kesimpulan

Pada contoh kedua yang ditampilkan Gambar 8 mencoba untuk menjelaskan lima contoh transaksi yang ada di perusahaan. Setelah semua transaksi dijelaskan persamaan akuntansinya, langkah berikutnya adalah memasukkan setiap transaksi ke dalam tabel persamaan akuntansi. Tabel tersebut dapat dilihat pada Gambar 9. Gambar ini menjelaskan bagaimana tabel persamaan akuntansi dibuat sampai dengan saldo akhir persamaan akuntansi. 
Uji validasi pakar materi diuji oleh Ibu Dra. Entri Sulistari Gundo, M.Si. (Kaprogdi Pendidikan Ekonomi FKIP UKSW). Hasil uji validasi materi menunjukkan bahwa video pembelajaran ekonomi-akuntansi berbasis YouTube termasuk dalam kategori baik dengan skor rata-rata 3,6. Aspek uji validasi ini mencakup substansi materi dan desain pembelajaran (Kemendiknas, 2010).

Tabel 1. Hasil Validasi Pakar Materi

\begin{tabular}{|l|l|c|c|}
\hline No. & \multicolumn{1}{|c|}{ Aspek } & Skor & Kategori \\
\hline 1. & Substansi materi & 3,6 & Baik \\
\hline 2. & $\begin{array}{l}\text { Desain } \\
\text { pembelajaran }\end{array}$ & 3,6 & Baik \\
\hline$\quad$ Rata-rata & $\mathbf{3 , 6}$ & Baik \\
\hline
\end{tabular}

Berdasarkan Tabel 1, hasil validasi materi menunjukkan bahwa video pembelajaran ekonomi-akuntansi berbasis YouTube sudah termasuk dalam kategori baik. Setiap aspek validasi materi juga termasuk dalam kategori baik. Beberapa catatan yang diberikan oleh pakar materi yaitu materi dilengkapi dengan contoh pemenuhan kebutuhan sehari-hari. Catatan tersebut yang menjadi dasar perbaikan video pembelajaran ini. Perbaikan yang telah disarankan oleh pakar ditunjukkan pada Gambar 7.

Uji validasi pakar media dilakukan oleh Bapak Adriyanto Juliastomo G., S.Si., M.Pd. (Dosen Pendidikan Teknologi Informatika dan Komputer UKSW). Hasil uji validasi pakar media menunjukkan kategori baik. Aspek uji validasi yang digunakan dalam penelitian ini meliputi tampilan komunikasi visual dan pemanfaatan software (Kemendiknas: 2010).

\section{Tabel 2. Hasil Validasi Pakar Media}

\begin{tabular}{|l|l|c|c|}
\hline No. & \multicolumn{1}{|c|}{ Aspek } & Skor & Kategori \\
\hline 1. & $\begin{array}{l}\text { Tampilan Komunikasi } \\
\text { Visual }\end{array}$ & 3,7 & Baik \\
\hline 2. & Pemanfaatan Software & 3,8 & Baik \\
\hline \multicolumn{2}{r|}{ Rata-rata } & $\mathbf{3 , 7}$ & Baik \\
\hline
\end{tabular}

Hasil validasi pakar media menunjukkan kategori baik dengan skor 3,7 untuk semua aspek. Begitu juga dengan setiap aspek masuk dalam kategori baik. Adapun beberapa saran dari pakar media meliputi lokasi pengambilan gambar yang disesuaikan dengan tema pembahasan, proses editing yang membuat beberapa bagian terlihat suara dan gerakan bibir tidak sama, beberapa bagian terlihat goyang sehingga perlu menggunakan stabilizer/ tripod. Perbaikan sesuai dengan masukkan pakar media dapat dilihat pada Gambar 7 dan 8 .

\section{Tahap Pengembangan dan Evaluasi}

Data angket yang telah diisi oleh 24 mahasiswa menunjukkan hasil positif. Hal ini ditunjukkan dari setiap aspek menghasilkan kategori baik. Ratarata pada semua kategori mencapai 4,02 yang dapat diartikan baik. 
Tabel 3. Hasil Pengisian Angket Uji Coba

\begin{tabular}{|l|l|c|c|}
\hline No. & \multicolumn{1}{|c|}{ Aspek } & Skor & Kategori \\
\hline 1. & Substansi materi & 4,0 & Baik \\
\hline 2. & Desain pembelajaran & 4,0 & Baik \\
\hline 3. & $\begin{array}{l}\text { Tampilan Komunikasi } \\
\text { Visual }\end{array}$ & 4,2 & Baik \\
\hline 4. & Pemanfaatan Software & 3,9 & Baik \\
\hline \multicolumn{2}{|}{ Rata-rata } & $\mathbf{4 , 0 2}$ & Baik \\
\hline
\end{tabular}

Hasil pengisian angket dilakukan setelah mahasiswa menyaksikan video pembelajaran ekonomi-akuntansi yang telah dibuat oleh peneliti. Mahasiswa dihadapkan pada 30 pernyataan yang diturunkan dari 4 aspek. Ada beberapa catatan yang ditangkap dari mahasiswa yaitu video yang disajikan menarik sebagai media pembelajaran, namun suara latar belakang membuat suara penyampai materi kurang jelas terdengar. Berdasarkan informasi yang diterima oleh peneliti ini, menjadi acuan perbaikan. Perbaikan tersebut dapat dilihat dari Gambar 2-9.

\section{Pembahasan}

Video pembelajaran ekonomi-akuntansi berbasis YouTube ini dilengkapi dengan efek suara dan animasi. Hal ini membuat mahasiswa lebih tertarik untuk menyimak dan mempelajari materi yang disajikan. Pernyataan ini didukung dengan pernyataan berikut: vlog digunakan sebagai media pembelajaran dan meningkatkan antusiasme belajar (Darmawan, 2016). Selain itu, media pembelajaran video juga dapat meningkatkan prestasi oral (Hung et.al., 2015), dan membangun rasa percaya diri (Snelson, 2015). Penyajian materi dalam video dengan tambahan animasi dan situasi yang diciptakan dalam video tersebut membuat materi yang sebelumnya dianggap rumit menjadi lebih sederhana.

Materi dilengkapi dengan contoh kasus pada kehidupan sehari-hari mahasiswa guna mempermudah dalam memahami materi. Setelah diberikan contoh kasus kehidupan sehari-hari, lalu diberikan contoh kasus pada perusahaan. Contoh-contoh yang diberikan membantu pemahaman materi yang dimaksud. Pembelajaran dengan video ini lebih diminati oleh mahasiswa. Hal ini didukung dengan temuan bahwa fitur video pembelajaran sangat diminati siswa dibandingkan dengan fitur lainnya (Susanto dkk, 2014). Selain itu, adanya kolom komentar yang disajikan pada YouTube mempermudah diskusi ataupun tanya jawab dimanapun dan kapanpun mahasiswa berada. Sama seperti temuan bahwa penggunaan kolom komentar pada media pembelajaran vlog sudah mulai digunakan walaupun belum secara maksimal (Bou et.al., 2012). Pengembangan media pembelajaran berbasis YouTube ini juga menjadi bukti nyata bahwa pembelajaran tidak hanya dilakukan secara konvensional, namun dapat juga disajikan pada YouTube. Seperti halnya pernyataan ini yaitu YouTube menjadi salah satu alat pembelajaran yang digemari (Mayoral et.al., 2010).

Adanya pengembangan media pembelajaran melalui video ini menunjukkan kreatifitas peneliti dalam menyampaikan materi kepada mahasiswa. Kreatifitas seperti ini dapat menumbuhkan cara pemahaman materi 
secara efektif. Keefektifan dalam mempelajari materi dapat meningkatkan performa pengguna dalam pembelajaran (Krasna et.al., 2014). Oleh sebab itu, dengan adanya kemudahan mengakses dan memahami materi yang disajikan maka media pembelajaran berbasis YouTube layak untuk digunakan. Hal ini didukung dengan pernyataan bahwa vlog layak digunakan sebagai media pembelajaran (Darmawan, 2016 dan Yuniati, 2014).

\section{SIMPULAN}

Video pembelajaran ekonomi-akuntansi berbasis YouTube yang dibuat oleh peneliti dapat dikatakan layak. Hal ini ditunjukan berdasarkan hasil uji pakar materi dan media serta uji coba kepada mahasiswa semuanya pada kategori baik. Hasil uji pakar materi berada pada rata-rata 3,6 (baik). Hasil uji pakar media menunjukkan rata-rata 3,7 (baik). Rata-rata hasil uji coba kepada mahasiswa mencapai 4,02 (baik). Video pembelajaran yang dibuat oleh peneliti juga memberikan ketertarikan tersendiri bagi para mahasiswa. Hal ini terlihat ketika mahasiswa benar-benar menyimak materi yang disampaikan namun menyimak dalam keadaan santai. Mahasiswa juga merasa tidak mudah bosan dalam proses pembelajaran.

Keterbatasan pengembangan pada penelitian ini yaitu kurangnya alat-alat yang memadai untuk melakukan perekaman. Pembuatan video pada penelitian ini hanya menggunakan kamera smartphone sehingga kualitas gambar dan suara kurang maksimal. Materi yang disajikan hanya terbatas pada satu kompetensi dasar saja. Oleh karena itu, saran untuk penelitian selanjutnya dapat menambahkan materi pada kompetendi dasar lainnya, menggunakan alatalat yang memadai, serta dapat menggunakan aplikasi pembuatan media pembelajaran yang lainnya supaya lebih banyak variasi video pembelajaran yang tersedia.

\section{DAFTAR RUJUKAN}

Ali, Muhamad. 2009. Pengembangan Media Pembelajaran Interaktif Mata Kuliah Medan Elektromagnetik. Jurnal Edukasi Elektro. Vol. 5 No. 1. Hal. 11-18.

Anitah, Sri. 2012. Media Pembelajaran. Surakarta: Yuma Pustaka.

Bere, Sigiranus Marutho. 2016. Jokowi: Anak Harus Dilindungi dari Dampak Negatif Teknologi. Kompas. Edisi Sabtu 30 Juli.

Bou et.al. 2012. Social Interaction in YouTube Text-Based Polylogues: A Study of Coherence. Journal of Computer-Merdiated Communication. Vol. 17. Hal. 501-521.

Combe, Christelle et.al. 2016. Vlogging: A New Channel for Language Learning and Intercultural Exchanges. Eurocall. Hal.119-124.

Darmawan, Reka et.al. 2016. The Development of Vlogging as Learning Media to Improve Student's Learning Enthusiasm on MYOB Manufacture (Debt Card) Material. Jurnal Kajian Pendidikan Akuntansi Indonesia Edisi 3. 
Hamzah, Ardi. 2013. Pengaruh Sosiologi Kritis, Kreatifitas, Dan Mentalitas Terhadap Pendidikan Akuntansi. E-Journal UIN Malang. Vol.2 No.1.

Hess, Mary E. 2014. A New Culture of Learning: Digital Storytelling and Faith Formation. Dialog: A Journal of Theology. Vol. 53 No.1.

Hung, Shao Ting Alan et.al. 2015. Video Blogging and English Presentation Performance: A Pilot Study. Psychological Reports: Sociocultural Issues in Psychology. Hal. 614-630.

Kemendigbud. 2016. Kompetensi Inti dan Kompetensi Dasar Pendidikan Dasar dan Menengah. Jakarta. Kementrian Pendidikan Nasional Direktorat Jenderal Manajemen Pendidikan Dasar dan Menengah.

Kemendiknas. 2010. Panduan Pengembangan Bahan Ajar Berbasis TIK. Jakarta: Kementrian Pendidikan Nasional Direktorat Jenderal Manajemen Pendidikan Dasar dan Menengah.

Krasna, Marjan et.al. 2014. Video Learning Materials for Better Sudent's Performance. CECIIS September. Hal. 130-137.

Mayoral et.al. 2010. YouTube Based Learning. FIG Congress. Edisi April. Hal. 11-16

Nistanto, Reska K. 2017. Ibu Ini Bangun Rumah Berbekal Video Tutorial di YouTube. Kompas. Edisi Selasa 24 Januari.

Nugrahani, Rahina. 2007. Media Pembelajaran Berbasis Visual Berbentuk Permainan Ular Tangga untuk Meningkatkan Kualitas Belajar Mengajar Di Sekolah Dasar. LIK Unnes. Vol. 36 No.1. Hal. 35-44.

Pritandhari, Meyta et.al. 2015. Evaluasi Penggunaan Video Tutorial sebagai Media Pembelajaran Semester IV Program Studi Pendidikan Ekonomi Universitas Muhammadiyah Metro. Jurnal PROMOSI. Vol. 3 No. 2. Hal. 11-20.

Raikos, Athanasios et.al. 2014. How Useful is YouTube in Learning Heart Anatomy?. Anatomical Sciences Education. Edisi 7. Hal. 12-18.

Riyana, Cepi. 2008. Peranan Teknologi dalam Pembelajaran. Universitas Indonesia. Jakarta.

Sianipar, Aritas Puica. 2013. Pemafaatan YouTube di Kalangan Mahasiswa. Flow. Vol. 2 No. 2.

Setyorini. 2016. Belajar Nyanyi Sampai Memasak, Semua Bisa dari YouTube. Kompas. Edisi Selasa 9 Februari.

Snelson, Chareen. 2015. Vlogging about School on YouTube: An Exploratory Study. SAGE new media \& society. Vol. 17 (3). Hal. 321-339.

Sukmadinata, Nana Syaodih. (2007). Metode Penelitian Pendidikan, Bandung; Remaja Rosda Karya.

Susanto dkk. 2014. Optimalisasi Perencanaan Video Pembelajaran Bahasa Inggris Berbasis Web. Jurnal Bahasa \& Sastra. Edisi Oktober. Vol. 14. No. 2. 
Wahono, Tri. 2010. YouTube dan Facebook Jadi Media Belajar. Kompas. Edisi Senin 16 Agustus.

Wibawa, Shierine Wangsa. 2017. Belajar dari YouTube, Kini Fredy Wijaya Kolaborasi dengan Disney. Kompas. Edisi Jumat 3 Maret.

Widiartanto, Yoga Hastyadi. 2016. Mengapa ICMI Minta Pemerintah Blokir Google dan YouTube?. Kompas. Edisi Rabu 8 Juni.

Yuniati. 2014. Pemanfaatan Video Dokumenter Hasil Kajian Peninggalan Sejarah Sebagai Media Pembelajaran Sejarah. Indonesian Journal of History Education. Vol. 3 No. 2. Hal. 36-41. 